\title{
Morphology and Morphogenesis of A New Soil Ciliate, Holostichides Songi Nov. Spec. with Notes on the Phylogeny of Holostichides (Ciliophora, Hypotrichia)
}

Jingyi Wang

Shaanxi Normal University

Jingbao Li

Northwestern Polytechnical University

Yurui Wang

Shaanxi Normal University

Chen Shao ( $\square$ Andrews1201@hotmail.com )

Shaanxi Normal University

Research article

Keywords: Morphology, New species, Ontogenesis, Phylogeny, Soil

Posted Date: June 11th, 2020

DOl: https://doi.org/10.21203/rs.3.rs-33941/v1

License: (c) (i) This work is licensed under a Creative Commons Attribution 4.0 International License.

Read Full License 


\section{Abstract}

Background: Hypotrichia are a group with the most complex morphology and morphogenesis within the ciliated protists. The classification of the genus Holostichides is poorly understood particularly due to the lack of molecular data. Hence, the systematic relationship between this genus and other taxa in the subclass Hypotrichia remains unresolved. In this paper, the morphology and morphogenesis of Holostichides songinov. spec. were studied, in addition, genomic DNA was extracted in order to sequence the small subunit rDNA. The main aims of this study were to document morphogenesis in $\mathrm{H}$. songinov. spec. and investigate the systematics of Holostichides based on morphology, morphogenetic, and molecular data.

Results: A new bakuellid ciliate, Holostichides songi nov. spec. isolated from China, is investigated in terms of its morphology, ontogenesis, and molecular phylogenesis. It is characterized by size in vivo 150-180 $\mu \mathrm{m} \times 45-60 \mu \mathrm{m} ; 27-46$ macronuclear nodules; cortical granules dark, spherical, about $0.5 \mu \mathrm{m}$ across, clustered in groups and then arranged longitudinally; three frontal cirri with one to four smaller cirri below the middle one, one buccal cirrus, 9-15 frontoterminal cirri, and midventral complex composed of five to eight cirral pairs and two long midventral rows. The main events during binary fission are as follows: (1) in the proter, the undulating membrane anlage is formed from both the dedifferentiation of old undulating membranes and the basal bodies developing de novo, and the posterior part of the parental adoral zone of membranelles is renewed by new structure formed from the oral primordium; (2) in the opisthe, the oral primordium is formed intrakinetally; (3) Besides the second frontal cirrus and buccal cirrus, the frontoventral-transverse cirral anlage II produces the extra one to four cirri. Phylogenetic analyses based on SSU rDNA sequence data suggest a close relationship between Holostichides songi nov. spec. and its congeners, indicating that the genus Holostichides is monophyletic.

Conclusions: The new bakuellid ciliate, Holostichides songi nov. spec. was studied using standard methods. In addition, the monophyly of the genus Holostichides is well supported in the phylogenetic tree.

\section{Background}

In recent years there have been significant advances in the knowledge and understanding of the taxonomy and systematics of hypotrichous ciliates. This is largely due to the application of silver impregnation methods to reveal the infraciliature, silverline system and other characters of taxonomic importance [1-6]. Moreover, a great diversity of species and basic modes of formation of ciliature and developmental events have been reported [7-13].

The bakuellid genus Holostichides was established by Foissner [14] with H. chardezi Foissner, 1987 as the type species, and was defined as follows: adoral zone of membranelles continuous; three frontal cirri; buccal cirrus(i) present; and three or more frontoterminal cirri; midventral complex composed of midventral pairs and one or more midventral rows; transverse cirri lacking; one left and one right marginal 
row; four or five dorsal kineties; caudal cirri present. Up to date, five species have been assigned to this genus: H. chardezi Foissner, 1987, H. dumonti Foissner, 2000, H. typicus (Song \& Wilbert, 1988) Eigner, 1994, H. heterotypicus Kim et al., 2017 and H. obliquocirratus Jung et al., 2019.

In May 23, 2018, an unknown hypotrichous ciliate was isolated from China. Observations of its morphology both in vivo and after protargol staining demonstrate that it represents a novel species within the genus Holostichides. In the present study, its morphology and morphogenesis are described. The small subunit ribosomal DNA (SSU rDNA) of the new isolate was sequenced and analysed in order to estimate its phylogenetic position.

\section{Results}

Holostichides songi nov. spec. (Figs. 1A-E, 2A-M, 3A-I, 4A-H, 5A-N, Table 1) 
Table 1

Morphometric characterization of Holostichides songi nov. spec.

\begin{tabular}{|c|c|c|c|c|c|c|c|c|}
\hline Character ${ }^{a}$ & $\mathrm{H}$ & Min & Max & Mean & M & SD & CV & $\mathbf{n}$ \\
\hline Body length & 145 & 126 & 173 & 147.9 & 146.0 & 14.2 & 9.6 & 25 \\
\hline Body width & 40 & 32 & 56 & 39.5 & 38.0 & 6.7 & 16.9 & 25 \\
\hline Body length: width, ratio & 3.6 & 2.8 & 4.3 & 3.8 & 3.9 & 0.4 & 9.5 & 25 \\
\hline Adoral zone, length & 50 & 35 & 53 & 44.2 & 44.0 & 4.6 & 10.5 & 25 \\
\hline Adoral zone length: body length, ratio & 0.34 & 0.26 & 0.35 & 0.30 & 0.30 & 0.02 & 6.3 & 25 \\
\hline Adoral membranelles, no. & 41 & 35 & 42 & 38.4 & 38.0 & 1.9 & 4.9 & 25 \\
\hline Frontal cirri, no. & 3 & 3 & 3 & 3.0 & 3.0 & 0 & 0 & 25 \\
\hline Buccal cirri, no. & 1 & 1 & 1 & 1.0 & 1.0 & 0 & 0 & 25 \\
\hline Frontoterminal cirri, no. & 13 & 9 & 15 & 11.0 & 11.0 & 1.4 & 12.3 & 25 \\
\hline $\begin{array}{l}\text { Cirri below the middle frontal cirrus, } \\
\text { no. }\end{array}$ & 3 & 1 & 4 & 2.5 & 2.0 & 0.7 & 28.8 & 25 \\
\hline Midventral pairs, no. & 8 & 5 & 8 & 6.5 & 7.0 & 0.9 & 13.4 & 25 \\
\hline Midventral rows, no. & 3 & 2 & 3 & 2.6 & 3.0 & 0.5 & 19.8 & 25 \\
\hline $\begin{array}{l}\text { The left long midventral row, number } \\
\text { of cirri }\end{array}$ & 12 & 6 & 12 & 8.1 & 8.0 & 1.6 & 20.4 & 23 \\
\hline $\begin{array}{l}\text { The right long midventral row, number } \\
\text { of cirri }\end{array}$ & 14 & 9 & 18 & 13.8 & 14.0 & 2.0 & 14.5 & 24 \\
\hline $\begin{array}{l}\text { The short midventral row, number of } \\
\text { cirri }\end{array}$ & 4 & 3 & 5 & 3.6 & 3.0 & 0.8 & 23.1 & 14 \\
\hline Cirri in right marginal row, no. & 46 & 36 & 53 & 44.2 & 43.0 & 5.4 & 12.2 & 25 \\
\hline Cirri in left marginal row, no. & 42 & 31 & 50 & 38.9 & 37.0 & 5.0 & 12.7 & 25 \\
\hline Caudal cirri, no. & 8 & 4 & 9 & 5.2 & 5.0 & 1.7 & 32.1 & 17 \\
\hline Dorsal kineties, no. & 4 & 4 & 4 & 4.0 & 4.0 & 0 & 0 & 24 \\
\hline Dorsal kinety 1 , bristles, no. & 26 & 18 & 30 & 24.8 & 25.0 & 2.9 & 11.6 & 25 \\
\hline Dorsal kinety 2, bristles, no. & 30 & 19 & 31 & 26.6 & 27.0 & 2.6 & 9.6 & 24 \\
\hline Dorsal kinety 3, bristles, no. & 26 & 19 & 28 & 23.6 & 23.5 & 2.3 & 9.6 & 22 \\
\hline
\end{tabular}

\footnotetext{
a All data is based on protargol-stained specimens, measurements in $\mu \mathrm{m}$. Abbreviations: $\mathrm{CV}$, coefficient of variation in \%; $\mathrm{H}$, holotype; $\mathrm{M}$, median; Max, maximum; Mean, arithmetic mean; Min, minimum; n, sample size; no., number; SD, standard deviation.
} 


\begin{tabular}{|lccccccccc|}
\hline Character $^{\text {a }}$ & H & Min & Max & Mean & M & SD & CV & n \\
\hline Dorsal kinety 4, bristles, no. & 29 & 20 & 31 & 27.8 & 28.0 & 2.6 & 9.4 & 21 \\
\hline Macronuclear nodule, no. & 34 & 27 & 46 & 34.6 & 33.0 & 5.5 & 16.0 & 25 \\
\hline Macronuclear nodule, length & 9 & 4 & 11 & 8.1 & 8.6 & 2.0 & 24.2 & 25 \\
\hline Macronuclear nodule, width & 5 & 4 & 7 & 5.1 & 5.2 & 1.1 & 21.8 & 25 \\
\hline Micronuclei, no. & 4 & 2 & 8 & 4.7 & 4.0 & 2.0 & 41.7 & 25 \\
\hline $\begin{array}{l}\text { a All data is based on protargol-stained specimens, measurements in pm. Abbreviations: CV, } \\
\text { coefficient of variation in \%; H, holotype; M, median; Max, maximum; Mean, arithmetic mean; Min, } \\
\text { minimum; n, sample size; no., number; SD, standard deviation. }\end{array}$ & \\
\hline
\end{tabular}

\section{Zoobank Registration}

Present work: urn:Isid:zoobank.org:pub:3D13BEB2-15AE-4186-B5AC-BA9230C99738

Holostichides songinov. spec.:

urn:Isid:zoobank.org:act:2D0D0574-BAB4-4469-830F-7B7972B359B4

\section{Diagnosis:}

Body $150-180 \mu \mathrm{m} \times 45-60 \mu \mathrm{m}$ in vivo in size, flexible and elongate-elliptical. 27-46 macronuclear nodules. Contractile vacuole positioned at about $40 \%$ of body length near left margin, collecting canals present. Cortical granules dark, spherical, about $0.5 \mu \mathrm{m}$ across, clustered in groups and then arranged longitudinally. Adoral zone composed of 35-42 membranelles. Three frontal cirri and one to four smaller cirri below the middle frontal cirrus. One buccal and nine to 15 frontoterminal cirri. Midventral complex composed of five to eight cirral pairs and two long midventral rows. One left and one right marginal cirral rows, composed of 31-50 and 36-53 cirri, respectively. Four bipolar dorsal kineties and four to nine caudal cirri.

\section{Type Material:}

The protargol slide (registry no. WJY2018052301B) with the holotype specimen and one paratype slide (registry no. WJY2018052301C) were deposited in the Laboratory of Protozoological Biodiversity and Evolution in Wetland, Shaanxi Normal University, China.

\section{Type Locality:}


Soil from the surface of soil in Egret Wetland Park, Suzhou, China $\left(31^{\circ} 16^{\prime} 18^{\prime \prime} \mathrm{N} ; 120^{\circ} 43^{\prime} 18^{\prime \prime} \mathrm{E}\right)$.

\section{Etymology:}

This species is named after the eminent ciliatologist Prof. Dr. Weibo Song, Ocean University of China, Qingdao, for his tremendous contribution to the ciliatology.

\section{Morphology (figs. a-e, A-m, Table )}

Body size in vivo $150-180 \mu \mathrm{m} \times 45-60 \mu \mathrm{m}(\mathrm{n}=7)$, and $126-173 \mu \mathrm{m} \times 32-56 \mu \mathrm{m}$ after protargol staining (Table 1). Body elongate-elliptical, rather flexible, but not contractile (Figs. 1A, 2A-C). Ratio of length to width after protargol preparation about 3.8:1, dorsoventrally flattened about 2:1. 27-46 ellipsoidal or spherical macronuclear nodules, 4-11 $\mu \mathrm{m} \times 4-7 \mu \mathrm{m}$ in size (after protargol staining), two to eight micronuclei scattered throughout the cytoplasm (Fig. 1E, 2L). Contractile vacuole about $12 \mu \mathrm{m}$ across when fully extended, positioned at about $40 \%$ of body length near left margin, pulsing at intervals of about $10 \mathrm{~s}$, collecting canals visible during diastole (Figs. 1A, 2B, C). Pellicle thin and soft, with cortical granules dark, spherical, about $0.5 \mu \mathrm{m}$ across, clustered in groups and then arranged longitudinally (Figs. 1B, 2D, E). Cytoplasm hyaline colorless to grayish, containing some lipid droplets $(0.5-4 \mu \mathrm{m}$ around) and food vacuoles (6-10 $\mu \mathrm{m}$ around) in posterior portion that render cell opaque and dark in posterior portion at low magnification, usually many irregular crystals located in posterior portion of cell (Fig. 2A). Locomotion by crawling slowly on plant debris or on the bottom of the Petri dish, occasionally swimming with slight rotation around long body axis.

Most cirri relatively fine, cilia about 10-12 $\mu \mathrm{m}$ long in vivo except for frontal cirri, cilia about $15 \mu \mathrm{m}$. Three slightly enlarged frontal cirri arranged in a transverse "pseudo" row with one to four smaller cirri longitudinally arranged below the middle frontal cirrus. Buccal cirrus located slightly anterior to intersection of endoral and paroral. Nine to 15 frontoterminal cirri locate to the right of midventral complex, start at about $1 / 4$ of adoral zone and terminate at about proximal end of adoral zone. Midventral complex composed of five to eight cirral pairs, extending to about the proximal end of adoral zone, usually together with two or three midventral rows, from right to left comprised of nine to 18 , six to 12 and three to five (if present) cirri, respectively. One right and one left marginal row composed of 36-53 and 31-50 cirri, respectively. Right marginal row starts at about $40 \%$ of adoral zone; left marginal row commences more or less at level of buccal vertex, both terminate caudally but not confluent posteriorly (Figs. 1D, 2F-K).

Invariably, four bipolar dorsal kineties, composed of 18-30, 19-31, 19-28, and 20-31 dikinetids, respectively. Bristles about $3 \mu \mathrm{m}$ long in life. Four to nine caudal cirri with cilia about $15 \mu \mathrm{m}$ long (Figs. 1E, 2M). 
Adoral zone occupies about $30 \%$ of body length in protargol preparations, composed of 35-42 membranelles, cilia of which are about $15 \mu \mathrm{m}$ long (Fig. 1A, D). Paroral and endoral in Oxytricha pattern, intersect optically somewhat behind level of buccal cirrus, and almost equal in length (Fig. 1C, D).

\section{Morphogenesis (figs. a-i, A-h, A-n)}

\section{Stomatogenesis}

Stomatogenesis commences with the intrakinetally formation of several groups of closely spaced basal bodies near the left midventral row, which is the oral primordium of the opisthe (Figs. 3A, 5A). Then, these groups merge by further proliferation of basal bodies forming a single anarchic field that becomes wider and wedge-shaped (Figs. 3B, C, 5B, C). Meanwhile, in the proter, a spherical field of basal bodies appears apokinetally to the left of the undulating membranes and seems to develop on the dorsal wall of the buccal cavity (Figs. 3C, 5D). Then the oral primordium of opisthe continues to grow by further proliferation of basal bodies and the new membranelles differentiate posteriad. Simultaneously, the old undulating membranes begin to dedifferentiate, which along with the spherical field of basal bodies to form the undulating membranes anlage for the proter (Figs. 3D, E, 5E, F). Subsequently, the undulating membranes anlagen appear on the right both in opisthe and proter, interestingly, another spherical field of basal bodies appears at the proximal end of old adoral zone of membranelles, which will form the new membranelles for the proter (Figs. 3F, 5H). In the middle stage, the undulating membranes anlage splits longitudinally to form two streaks from which the endoral and paroral derive, and gives rise to the leftmost frontal cirrus in each the proter and opisthe. The proximal membranelles in the proter are replaced by newly formed structures (Figs. $3 \mathrm{H}, 5 \mathrm{~L}$ ). In the late stages, the differentiation of membranelles is almost complete, forming the new structures for both the daughter cells, anterior end of the new adoral in opisthe bends to the right. Initially, the newly formed endoral and paroral initially lie close together in parallel, but later they separate, arch, and intersect in each filia product (Fig. 4A, C, E, G).

\section{Development Of The Frontoventral-transverse Cirri}

In the early stage, some cirri in the midventral complex dedifferentiate to join in the construction of the frontoventral-transverse cirral anlagen (FVT-anlagen) (Figs. 3D, E, 5F). Subsequently, the FVT-anlagen form and lengthen by increasing the number of basal bodies, to the right of the undulating membranes anlagen in both the opisthe and proter (Figs. 3E, F, 5G, J). In the middle stage, these anlagen broaden and break apart (Figs. 3H, 5L). In late stages, the FVT-anlagen commence to fragmentize (Figs. 4A, C, 5N). Later, the segregation of cirri from the FVT-anlagen is almost complete and, the old structures are almost resorbed. New cirri migrate to their final positions as distinct cirri (Fig. 4E, G). Consequently, anlage I provides the left frontal cirrus; anlage II forms the middle frontal cirrus, the cirri below the middle frontal cirrus and the buccal cirrus; anlage III produces the rightmost frontal cirrus and the cirrus III/2; midventral 
pairs develop from anlagen IV to $n-4$ (in some individuals, $n-3$ ) and midventral rows are formed from anlagen $n-3$ (in some individuals, $n-2$ ) to $n-1$; anlage $n$ forms the frontoterminal cirri (Fig. 4E, G).

\section{Development Of Marginal Rows And Dorsal Kineties}

The marginal and dorsal kineties anlagen are formed intrakinetally both in the proter and the opisthe (Figs. 3F, G, 5J). These anlagen subsequently elongate and gradually replace the parental structures (Figs. $3 \mathrm{H}, \mathrm{I}, 4 \mathrm{~A}-\mathrm{H}, 5 \mathrm{~K}, \mathrm{~N}$ ). Four to nine caudal cirri are formed at the posterior ends of dorsal kineties (Fig. 4B, D, F, H).

\section{Division Of Nuclear Apparatus}

The nuclear apparatus divides in the usual way for urostylids. Briefly, the two macronuclear nodules fuse to form a single mass during the mid-divisional stage and then divide twice prior to cytokinesis. Micronuclei were observed to divide mitotically (Figs. 3G, I, 4B, D, F, H, 5I, M).

\section{Phylogenetic analyses based on SSU rDNA gene sequences (Fig. 6)}

The SSU rDNA sequence of Holostichides songi nov. spec. was deposited in GenBank with the accession number MT557692. The length and GC content of the new sequence are 1651 bp and 45\%, respectively.

Phylogenetic trees using two different methods ( $\mathrm{ML}$ and $\mathrm{BI}$ ) generated nearly congruent relationships. Therefore, only the ML tree is presented with support values from both algorithms at the nodes (Fig. 6). In both analyses, Holostichides songinov. spec. clusters with its congeners, namely $\mathrm{H}$. chardezi, $\mathrm{H}$. heterotypicus and $H$. obliquocirratus, with full support. The similarities of the SSU rDNA sequence of $H$. songi nov. spec. to $H$. chardezi, H. heterotypicus and $H$. obliquocirratus are $97.4 \%, 94.9 \%$ and $97.6 \%$, respectively.

\section{Discussion}

Morphological comparison of Holostichides songi nov. spec. with its congeners

Hitherto, there are five species in Holostichides, i.e. H. chardezi Foissner, 1987, H. dumonti Foissner, 2000, H. typicus (Song \& Wilbert, 1988) Eigner, 1994, H. heterotypicus Kim et al., 2017 and H. obliquocirratus Jung et al., 2019. They are compared with the new species as follows:

Holostichides songinov. spec. can be distinguished from $\mathrm{H}$. chardezi by having dark (vs. yellowish green) cortical granules, more frontoterminal cirri (nine to $15 \mathrm{vs.} \mathrm{three} \mathrm{to} \mathrm{seven)} \mathrm{and} \mathrm{long} \mathrm{midventral} \mathrm{rows} \mathrm{(two}$ vs. one), as well as cirri below the middle frontal cirrus (vs. absent). Furthermore, the sequence similarity between $H$. songi nov. spec. and $H$. chardezi is $97.4 \%$ [15]. 
Holostichides songinov. spec. differs from H. dumonti in body length (150-180 $\mu \mathrm{m}$ vs. 190-280 $\mu \mathrm{m})$, arrangement and colour of cortical granules (in groups, dark vs. in longitudinal row, colourless), the numbers of macronuclear nodules (27-46 vs. 100-150), frontoterminal cirri (nine to $15 \mathrm{vs.} \mathrm{two} \mathrm{to} \mathrm{five)}$ and dorsal kineties (four vs. five or six), as well as the cirri below the middle frontal cirrus present (vs. absent) [16].

Holostichides songinov. spec. can be separated from $H$. heterotypicus by having cirri below the middle frontal cirrus (vs. absent) and dark (vs. colourless) cortical granules. Furthermore, the sequence similarity between $H$. songi nov. spec. and $H$. heterotypicus is $94.9 \%$ [17].

Holostichides songinov. spec. can be distinguished from $\mathrm{H}$. obliquocirratus by the dark (vs. yellowish) cortical granules, and the cirri below the middle frontal cirrus present (vs. absent). Furthermore, the sequence similarity between $H$. songinov. spec. and $H$. obliquocirratus is $97.6 \%$ [18].

Holostichides songinov. spec. differs from H. typicus in cortical granules present (vs. absent) and cirri below the middle frontal cirrus present (vs. absent) [19].

\section{Morphogenetic Comparison With Congeners}

Morphogenetic processes have been reported for three Holostichides species, namely, H. chardezi, $H$. typicus and $H$. heterotypicus $[1,15,17,19]$. The species of Holostichides, however, exhibit great diversity in their ontogenetic processes, e.g.: (1) in $H$. songinov. spec., besides the second frontal cirrus and buccal cirrus, the FVT-anlagen II produces the extra one to four cirri, while they are not formed in other three species; (2) the oral primordium of the opisthe develop intrakinetally in H. songi nov. spec., H. typicus and H. heterotypicus, whereas in $\mathrm{H}$. chardezi, it is formed apokinetally; (3) the oral primordium develops in the proter in $\mathrm{H}$. songi nov. spec., whereas the parental adoral zone of membranelles is reorganized in situ in $H$. chardezi, H. typicus and $H$. heterotypicus; (4) the undulating membranes anlage are formed from the dedifferentiation of the parental undulating membranes only in $H$. chardezi, $H$. typicus and $H$. heterotypicus, while in $\mathrm{H}$. songinov. spec., the undulating membrane anlage are formed from both the dedifferentiation of parental undulating membranes and the basal bodies developing de novo.

\section{Phylogenetic Analyses}

The SSU rDNA sequence of Holostichides songinov. spec. and those of 66 other hypotrichs were downloaded from GenBank database for the phylogenetic analyses (for accession numbers, see Fig. 6). Four euplotid species, namely Apodiophrys ovalis, Diophrys scutum, Paradiophrys zhangi and Uronychia multicirrus, were used as outgroup taxa. Sequences were aligned using the GUIDANCE web server (http://guidance.tau.ac.il/, [29]). Both ends of the alignments were trimmed and ambiguous columns were removed based on confidence scores calculated by GUIDANCE. Maximum likelihood (ML) analyses were performed using RAxML-HPC2 on XSEDE v8.2.9 [30, 31] on the online server CIPRES Science 
Gateway (http://www.phylo.org/portal2/login!input.action, [32]). The reliability of internal branches was assessed using a nonparametric bootstrap method with 1000 replicates. Bayesian inference (BI) analyses were carried out using MrBayes on XSEDE v3.2.6 [33] on CIPRES Science Gateway with the GTR $+I+G$ model selected by Akaike Information Criterion (AIC) in MrModeltest v2 [34]. Markov chain Monte Carlo simulations were run with two sets of four chains for 2000000 generations with a sample frequency of 100 generations and discarding the first 5000 trees as a burn-in (25\%). All remaining trees were used to calculate posterior probabilities using a $50 \%$ majority rule consensus. MEGA v 5 was used to visualize the tree topologies [35].

\section{Conclusions}

In this manuscript, the new soil species, Holostichides songinov. spec. collected from the wetland, expand the knowledge of biodiversity of ciliates. Moreover, the monophyly of Holostichides is confirmed by the molecular phylogeny as the Holostichides species clustered in a well-supported clade.

\section{Methods}

\section{Sample collection, observation, and identification}

Samples (about $250 \mathrm{~g}$ ) were collected from the surface (top $10 \mathrm{~cm}$ ) of soil in Egret Wetland Park, Suzhou, China $\left(31^{\circ} 16^{\prime} 18^{\prime \prime} \mathrm{N} ; 120^{\circ} 43^{\prime} 18^{\prime \prime} \mathrm{E}\right)$ on May 23,2018 . Ciliates were made to excyst by employing the nonflooded Petri dish method as described by Foissner [14]. A non-clonal culture was established at room temperature (about $24^{\circ} \mathrm{C}$ ) in Petri dishes containing mineral water (Nongfu Spring) with squeezed rice grains to enrich the bacterial food. The species was accurately identified based on its in vivo morphologic characteristics. Moreover, no other Holostichides-morphotypes were present in the protargol preparation. The probability is therefore extremely high that the present morphological, morphogenetic and molecular studies deal with the same species.

Living cells were observed in vivo using bright field and differential interference contrast microscopy (Olympus BX53), and photographed using a digital camera. Protargol staining was used to reveal the ciliary pattern and nuclear apparatus [26]. Counts and measurements of stained specimens were performed with an ocular micrometer. Drawings were made with the help of a camera lucida. To illustrate the changes occurring during morphogenetic processes, old (parental) ciliary structures are depicted by contour whereas new structures are shaded black. Terminology is mainly according to Berger [1].

\section{Dna Extraction, Pcr Amplification, And Gene Sequencing}

One cell of Holostichides songinov. spec. was isolated and repeatedly washed using sterile distilled water. It was then transferred to a $1.5-\mathrm{ml}$ microfuge tube with a minimum volume of water. Genomic DNA was extracted from cells using DNeasy Blood \& Tissue Kit (Qiagen, CA) following the manufacturer's instructions. The PCR was amplified according to Gao et al. [27], using the eukaryotic universal SSU rDNA 
primers 18S-F (5'-AAC CTG GTT GAT CCT GCC AGT-3') and 18S-R (5'-TGA TCC TTC TGC AGG TTC ACC TAC-3') [28]. High-fidelity Taq polymerase (Takara Ex Taq; Takara Biomedicals) was used to minimize the possibility of amplification errors. Polymerase chain reaction conditions for the SSU rDNA amplification were as follows: $2 \mathrm{~min}$ initial denaturation $\left(98^{\circ} \mathrm{C}\right.$ ) followed by 30 cycles of denaturation for $10 \mathrm{~s}$ at $98^{\circ} \mathrm{C}$, annealing for $15 \mathrm{~s}$ at $56^{\circ} \mathrm{C}$, and extension for $1 \mathrm{~min} 50 \mathrm{~s}$ at $72{ }^{\circ} \mathrm{C}$, with a final extension of $7 \mathrm{~min}$ at $72{ }^{\circ} \mathrm{C}$. Sequencing in both directions was carried out on an ABI 3700 sequencer (Invitrogen sequencing facility, Shanghai, China) using primers 18S-F, 18S-R and three internal primers 900F (5'-CGA TCA GAT ACC GTC CTA GT-3'), 900R (5'-ACT AGG ACG GTA TCT GAT CG-3') and Pro B (5'-GGT TAA AAA GCT CGT AGT-3').

\section{Declarations}

\section{Ethics approval and consent to participate}

Not applicable.

\section{Consent for publication}

Not applicable.

\section{Availability of data and materials}

Sequence data are available in GenBank (Accession Number: MT557692).

The datasets used and/or analyzed during the current study are available from the corresponding author on reasonable request. One permanent slide containing the protargol-impregnated holotype specimen of Holostichides songinov. spec. (registry no. WJY2018052301B) and one paratype slide (registry no. WJY2018052301C) were deposited in the Laboratory of Protozoological Biodiversity and Evolution in Wetland, Shaanxi Normal University, China.

\section{Competing interests}

The authors declare that they have no competing interests.

\section{Funding}

This work was supported by the Natural Science Foundation of China (Project number: 31872190). The funding body had no role in study design, data collection, analysis and interpretation, and in writing of the manuscript.

\section{Authors' contributions}

JW collected the samples, carried out the live observation, protargol preparations and morphometrics and drafted the manuscript; JL was responsible for DNA amplification and sequencing, and drafted the manuscript; $Y W$ carried out the molecular phylogenetic analyses. CS did the identification of the species, 
taxonomic analysis and revision of the manuscript. All authors prepared the manuscript and approved the final version.

\section{Acknowledgements}

The authors would like to thank anonymous reviewers for their thoughtful critiques that helped improve the manuscript.

\section{References}

1. Berger H. Monograph of the Urostyloidea (Ciliophora, Hypotricha). Monogr Biol. 2006;85:1-1303.

2. Chen L, Dong J, Wu W, Xin Y, Warren A, Ning Y, et al Morphology and molecular phylogeny of a new hypotrich ciliate, Anteholosticha songinov. spec., and an American population of Holosticha pullaster (Müller, 1773) Foissner et al., 1991 (Ciliophora, Hypotrichia). Eur J Protistol. 2020;72:125646.

3. Jung JH, Berger H. Monographic treatment of Paraholosticha muscicola (Ciliophora, Keronopsidae), including morphological and molecular biological characterization of a brackish water population from Korea. Eur J Protistol. 2019;68:48-67.

4. Park KM, Jung JH, Jeong HK, Min GS, Kim S. Morphology, morphogenesis, and molecular phylogeny of a new freshwater ciliate, Gonostomum jangbogoensis n. sp. (Ciliophora, Hypotricha), from Victoria Land, Antarctica. Eur J Protistol. 2020;73:125669.

5. Wang J, Li J, Shao C. Morphology, morphogenesis, and molecular phylogeny of a novel saline soil ciliate, Heterourosomoida sinica n. sp. (Ciliophora, Hypotrichia). Eur J Protistol. 2020;73:125666.

6. Wang J, Zhao Y, Lu X, Lyu Z, Warren A, Shao C. Does the Gonostomum-patterned oral apparatus in hypotrichia carry a phylogenetic signal? Evidence from morphological and molecular data based on extended taxon sampling using three nuclear genes (Ciliophora, Spirotrichea). Sci China Life Sci. 2020;63, https://doi.org/10.1007/s11427-020-1667-3.

7. Bhartia D, Kumar S, Terza AL, Chandra K. Morphology and ontogeny of Tetmemena pustulata indica nov. subspec. (Ciliophora, Hypotricha), from the Thane Creek, Mumbai, India. Eur J Protistol. 2019;71:125629.

8. Foissner W. Terrestrial and semiterrestrial ciliates (Protozoa, Ciliophora) from Venezuela and Galápagos. Denisia. 2016;35:1-912.

9. Gao Y, Gong R, Jiang Y, Pan B, Li Y, Warren A, et al. Morphogenetic characters of the model ciliate Euplotes vannus (Ciliophora, Spirotrichea): Notes on cortical pattern formation during conjugational and postconjugational reorganization. Eur J Protistol. 2020;73:125675.

10. Hu X, Lin X, Song W. Ciliates Atlas: Species Found in the South China Sea. Beijing: Science Press; 2019.

11. Lian C, Luo X, Warren A, Zhao Y, Jiang J. Morphology and phylogeny of four marine or brackish water spirotrich ciliates from China, with descriptions of two new species. Eur $\mathrm{J}$ Protistol. 
2020;72:125663.

12. Song W, Shao C. Ontogenetic Patterns of Hypotrichs Ciliates. Science Press (in Chinese). 2017;12:1497.

13. Zhang T, Dong J, Cheng T, Duan L, Shao C. Reconsideration of the taxonomy of the marine ciliate Neobakuella aenigmatica Moon et al., 2019 (Protozoa, Ciliophora, Hypotrichia). Mar Life Sci Technol. 2020;2:97-108.

14. Foissner W. Soil protozoa: fundamental problems, ecological significance, adaptations in ciliates and testaceans, bioindicators, and guide to the literature. Progr Protistol. 1987;2:69-212.

15. Zhu E, Ba S, Lyu Z, Li J, Shao C. Morphogenesis and Molecular Phylogeny of the Soil Ciliate Holostichides chardezi (Ciliophora, Hypotrichia, Bakuellidae), with Redefinition of Holostichides Foissner, 1987 and Establishment of a New Genus Anteholostichides. J Eukaryot Microbiol. 2019;66:730-9.

16. Foissner W. A compilation of soil and moss ciliates (Protozoa, Ciliophora) from Germany, with new records and descriptions of new and insufficiently known species. Eur J Protistol. 2000;36:253-83.

17. Kim KS, Jung JH, Min GS. Morphology and molecular phylogeny of two new ciliates, Holostichides heterotypicus n. sp. and Holosticha muuiensis n. sp. (Ciliophora: Urostylida). J Eukaryot Microbiol. 2017;64:873-84.

18. Jung JH, Omar A, Kim KS, Kang SC, Kwak DY, Sun JH, et al. A study on the non-monophyletic genera Australothrix and Holostichides based on multigene and morphological analyses with a reexamination of type materials (Protozoa: Ciliophora). Mol Phylogenet Evol. 2019;139:106538.

19. Song W, Wilbert N. Parabakuella typica nov. gen., nov. spec. (Ciliata, Hypotrichida) aus dem Edaphon eines Standortes in Qingdao, China. Arch Protistenk. 1988;135:319-25.

20. Dai R, Xu K. Taxonomy and phylogeny of Tunicothrix (Ciliophora, Stichotrichia), with the description of two novel species, Tunicothrix brachysticha $\mathrm{n}$. sp. and Tunicothrix multinucleata $\mathrm{n}$, sp., and the establishment of Parabirojimidae n. fam. Int J Syst Evol Microbiol. 2011;61:1487-96.

21. Lyu Z, Wang J, Huang J, Warren A, Shao C. Multigene-based phylogeny of Urostylida (Ciliophora, Hypotrichia), with establishment of a novel family. Zoolog Scr. 2018;47:243-54.

22. Jiang J, Huang J, Li L, Shao C. Al-Rasheid KAS, Al-Farraj SA, et al. Morphology, ontogeny, and molecular phylogeny of two novel bakuellid-like hypotrichs (Ciliophora: Hypotrichia), with establishment of two new genera. Eur J Protistol. 2013;49:78-92.

23. Li L, Khan SN, Ji D, Shin MK, Berger H. Morphology and small subunit (SSU) rRNA gene sequence of the new brackish water ciliate Neobakuella flava n. g., n. sp. (Ciliophora, Spirotricha, Bakuellidae) and SSU rRNA gene sequences of six additional Hypotrichs from Korea. J Eukaryot Microbiol. 2011;58:339-51.

24. Chen X, Hu X, Lin X, Al-Rasheid KAS, Ma H, Miao M. Morphology, ontogeny and molecular phylogeny of a new brackish water ciliate Bakuella subtropica sp. n. (Ciliophora, Hypotricha) from southern China. Eur J Protistol. 2013;49:611-22. 
25. Zhang T, Qi H, Zhang T, Sheng Y, Warren A, Shao C. Morphology, morphogenesis and molecular phylogeny of a new brackish water subspecies, Neourostylopsis flava paraflava nov. subsp. (Ciliophora, Hypotrichia, Urostylidae), with redefinition of the genus Neourostylopsis. Eur J Protistol. 2019;66:48-62.

26. Wilbert N. Eine verbesserte technik der Protargolimprägnation für ciliaten. Mikrokosmos. 1975;64:171-9.

27. Gao F, Wang P, Katz LA, Gao S, Song W. Multigene-based phylogenetic analyses of cyclidiids (Protista, Ciliophora, Scuticociliatia) suggest its close relationship with thigmotrichids. Mol Phylogenet Evol. 2014;75:219-26.

28. Medlin L, Elwood HJ, Stickel S, Sogin ML. The characterization of enzymatically amplified eukaryotic 16S-like rRNA-coding regions. Gene. 1988;71:491-9.

29. Penn O, Privman E, Ashkenazy H, Landan G, Graur D, Pupko T. GUIDANCE: a web server for assessing alignment confidence scores. Nucleic Acids Res. 2010;38:W23-8.

30. Stamatakis A. RAxML version 8: a tool for phylogenetic analysis and post-analysis of large phylogenies. Bioinformatics. 2014;30:1312-3.

31. Stamatakis A, Hoover P, Rougemont J. A rapid bootstrap algorithm for the RAxML web-servers. Syst Biol. 2008;57:758-71.

32. Miller MA, Pfeiffer W, Schwartz T. Creating the CIPRES science gateway for inference of large phylogenetic trees. In: Proceedings of the Gateway Computing Environments Workshop (GCE), New Orleans, LA. 2010.

33. Ronquist F, Teslenko M, van der Mark P, Ayres DL, Darling A, Höhna S, et al. MrBayes 3.2: effıcient Bayesian phylogenetic inference and model choice across a large model space. Syst Biol. 2012;61:539-42.

34. Nylander JAA. MrModeltest. Version 2.2. Program distributed by the author. Evolutionary Biology Centre. Uppsala: Uppsala University; 2004.

35. Tamura K, Peterson D, Peterson N, Stecher G, Nei M, Kumar S. MEGA5: molecular evolutionary genetics analysis using maximum likelihood, evolutionary distance, and maximum parsimony methods. Mol Biol Evol. 2011;28:2731-9.

\section{Figures}



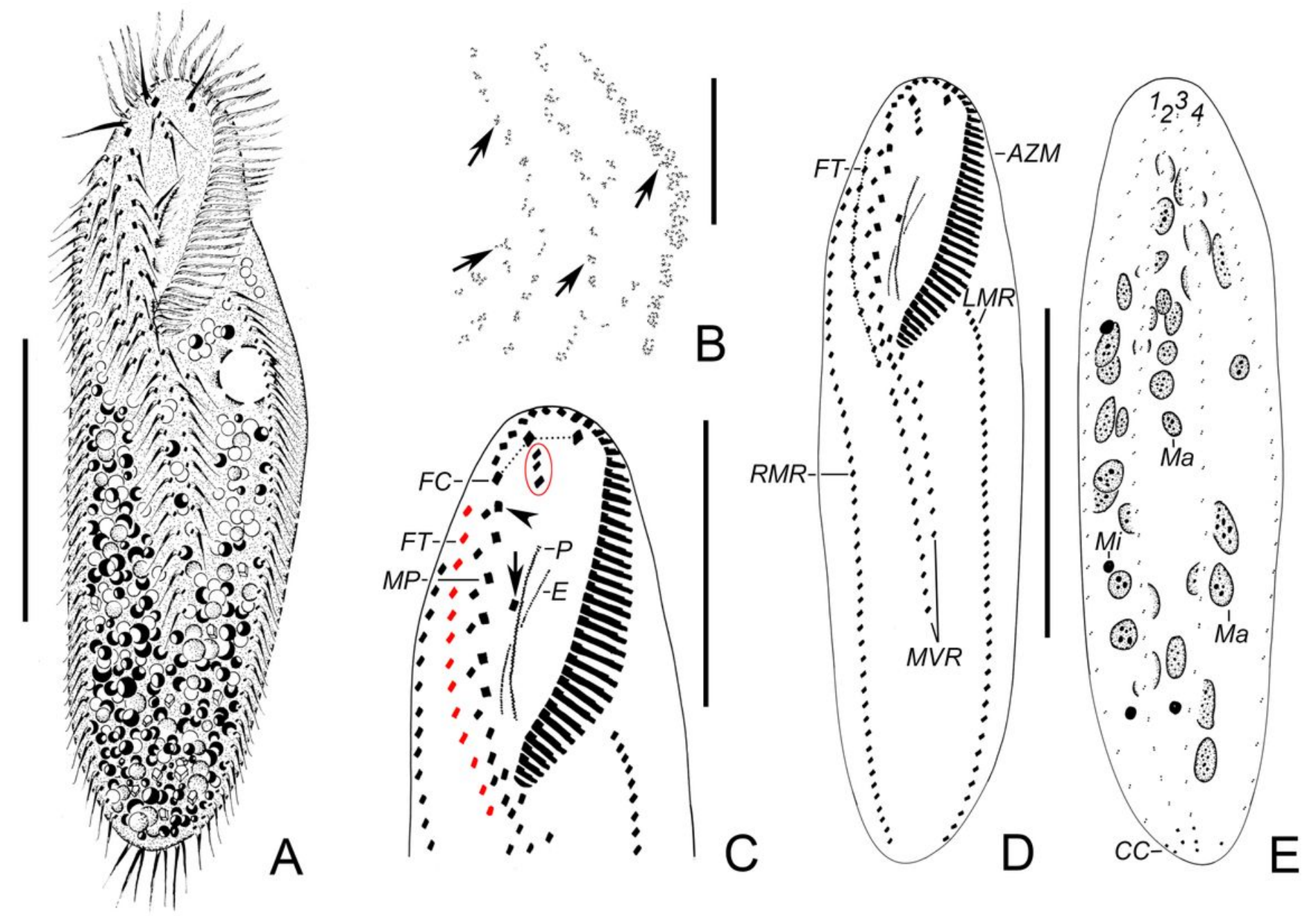

Figure 1

Morphology and infraciliature of Holostichides songi nov. spec. from life (A, B) and after protargol staining (C-E). (A) Ventral view of a representative individual. (B) Arrangement of the cortical granules (arrows). (C) Detailed ventral view of the anterior region, showing the frontal cirri, frontoterminal cirri, midventral pairs, buccal cirrus (arrow), cirrus III/2 (arrowhead), cirri below the middle frontal cirrus (in circle), as well as paroral and endoral. (D, E) Ventral (E) and dorsal (F) view of same specimen (holotype), to mark infraciliature and nuclear apparatus. AZM, adoral zone of membranelles; CC, caudal cirri; $\mathrm{E}$, endoral; FC, frontal cirri; FT, frontoterminal cirri; LMR, left marginal row; Ma, macronuclear nodules; $\mathrm{Mi}$, micronuclei; MP, midventral pair; MVR, midventral cirral row; P, paroral; RMR, right marginal row; 1-4, dorsal kineties. Scale bars $=60 \mu \mathrm{m}(\mathrm{A}, \mathrm{D}, \mathrm{E}) ; 30 \mu \mathrm{m}(\mathrm{C}) ; 20 \mu \mathrm{m}(\mathrm{B})$. 


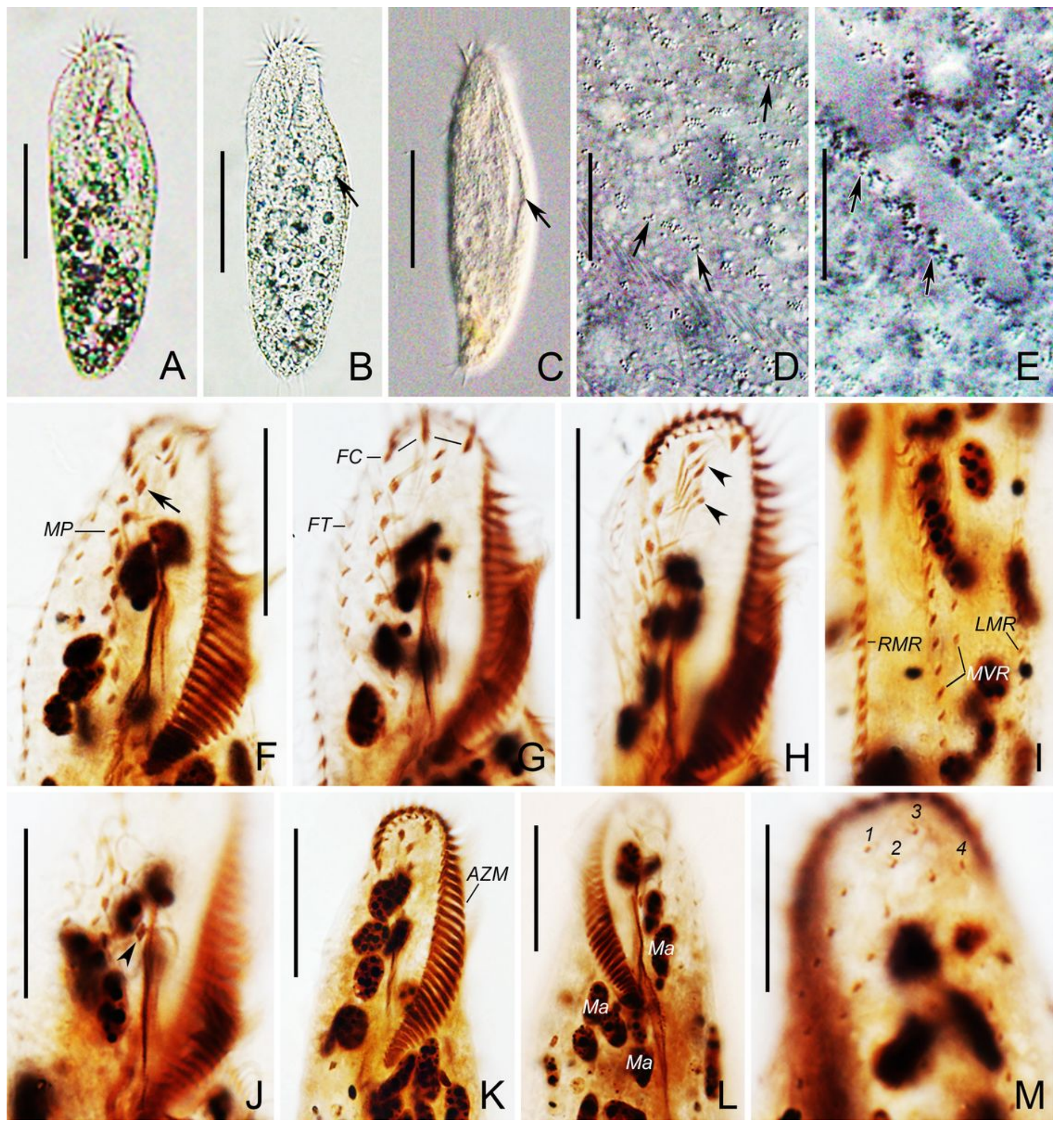

Figure 2

Photomicrographs of Holostichides songi nov. spec. from life (A-E) and after protargol staining ( $F-M)$. $(A, B)$ Ventral views of representative individuals to show body shape and the contractile vacuole (arrow). (C) Ventral view of a slightly squeezed specimen, arrow depicts the collecting canals. (D, E) Arrangement of cortical granules (arrows). (F-K) Ventral views to demonstrate the ciliature. Note the cirrus III/2 (arrow in F), midventral pairs (F), frontal cirri (G), frontoterminal cirri $(G)$, cirri below middle frontal cirrus 
(arrowheads in H), buccal cirrus (arrowhead in J), adoral zone of membranelles (K), midventral rows $(\mathrm{I})$ as well as left and right marginal rows $(I)$. ( $L, M)$ Dorsal views, to depict the macronuclear nodules and dorsal kineties. AZM, adoral zone of membranelles; FC, frontal cirri; FT, frontoterminal cirri; LMR, left marginal row; Ma, macronuclear nodules; MP, midventral pair; MVR, midventral cirral row; RMR, right marginal row; 1-4, dorsal kineties. Scale bars $=50 \mu \mathrm{m}(A-C), 20 \mu \mathrm{m}(D-H, J-M)$.
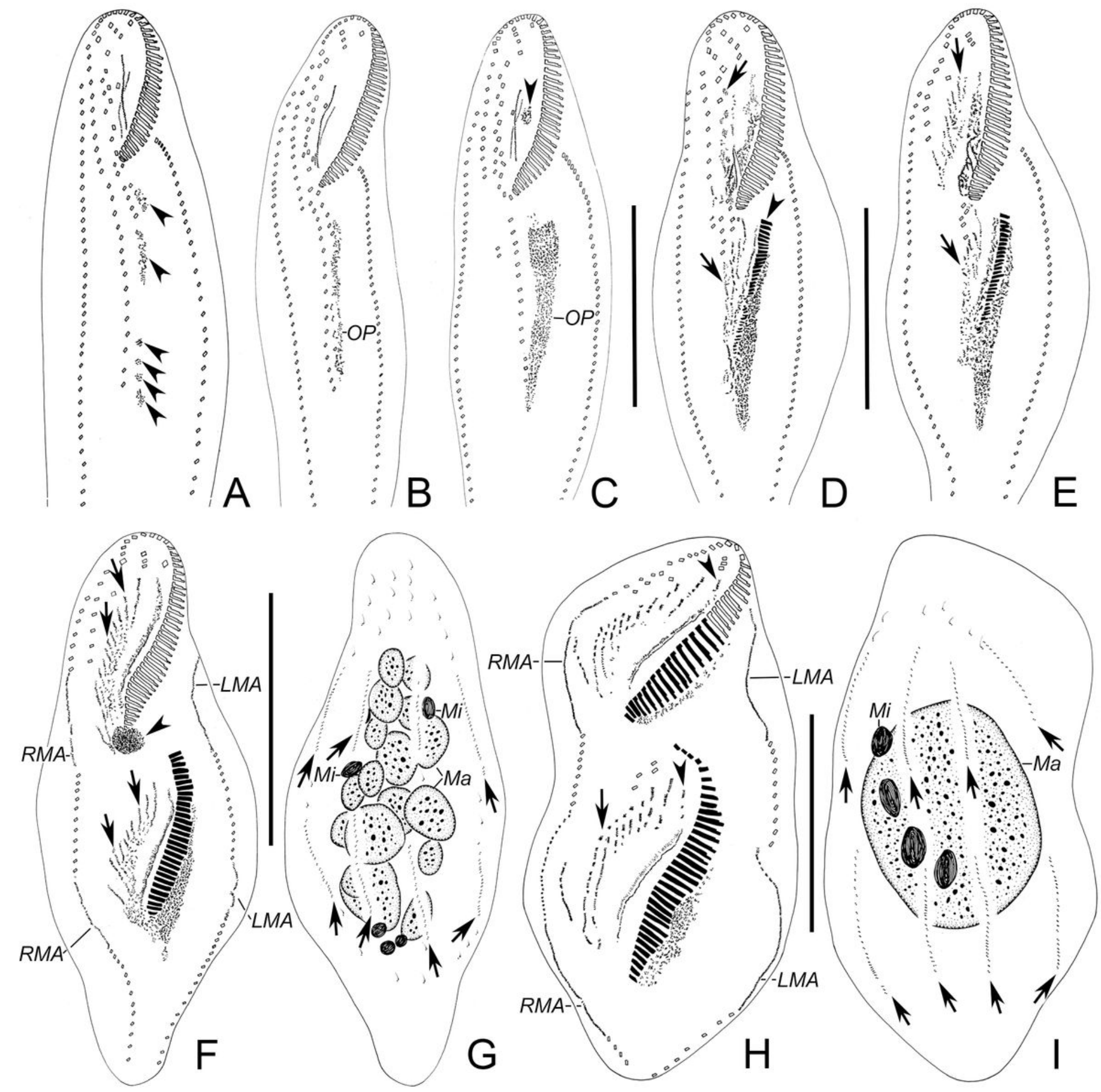

Figure 3 
Morphogenesis of Holostichides songi nov. spec. after protargol staining. (A, B) Ventral views of early stages, to denote the oral primordium of opisthe (arrowheads). (C) Ventral view, arrowhead shows that the oral primordium of proter appear apokinetally. (D, E) Ventral views, arrows mark the formation of the frontoventral-transverse cirral anlagen, arrowhead depicts the newly formed membranelles. $(F, G)$ Ventral (F) and dorsal (G) view of an early-middle divider, arrows in F show the frontoventral-transverse cirral anlagen and in $\mathrm{G}$ mark the dorsal kineties anlagen, while arrowhead indicates the basal bodies formed at the proximal end of old adoral zone. $(\mathrm{H}, \mathrm{I})$ Ventral $(\mathrm{H})$ and dorsal $(\mathrm{I})$ view of middle divider, arrows in $\mathrm{H}$ mark the segregation of the frontoventral-transverse cirral anlagen and in I show the dorsal kineties anlagen, as well as arrowheads demonstrate the first frontal cirri separated from the undulating membranes anlagen in both proter and opisthe. LMA, left marginal anlagen; Ma, macronuclear nodules; $\mathrm{Mi}$, micronuclei; OP, oral primordium; RMA, right marginal anlagen. Scale bars $=50 \mu \mathrm{m}$. 

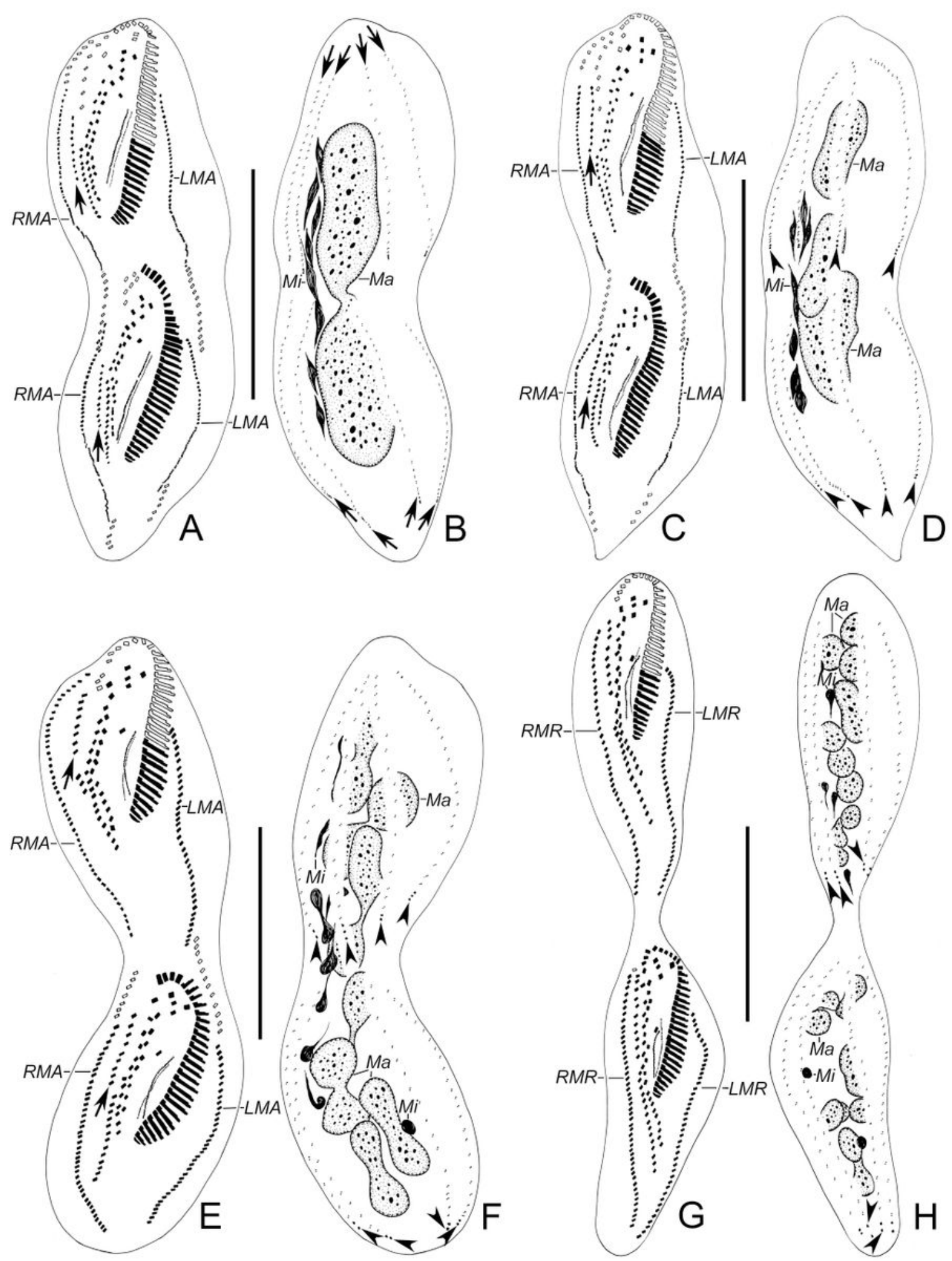

Figure 4

Late stages of morphogenesis in Holostichides songi nov. spec. after protargol staining. (A, B) Ventral (A) and dorsal (B) view, arrows in A show frontoterminal cirri migrating anteriad and in $B$ mark dorsal kineties anlagen. (C-H) Ventral $(C, E, G)$ and dorsal $(D, F, H)$ views of late dividers, to demonstrate the newly formed ciliature, including marginal cirral rows, midventral complex, frontoterminal cirri (arrows) and 
caudal cirri (arrowheads). LMA, left marginal anlagen; LMR, left marginal row; Ma, macronuclear nodules; $\mathrm{Mi}$, micronuclei; RMA, right marginal anlagen; RMR, right marginal row. Scale bars $=50 \mu \mathrm{m}$.
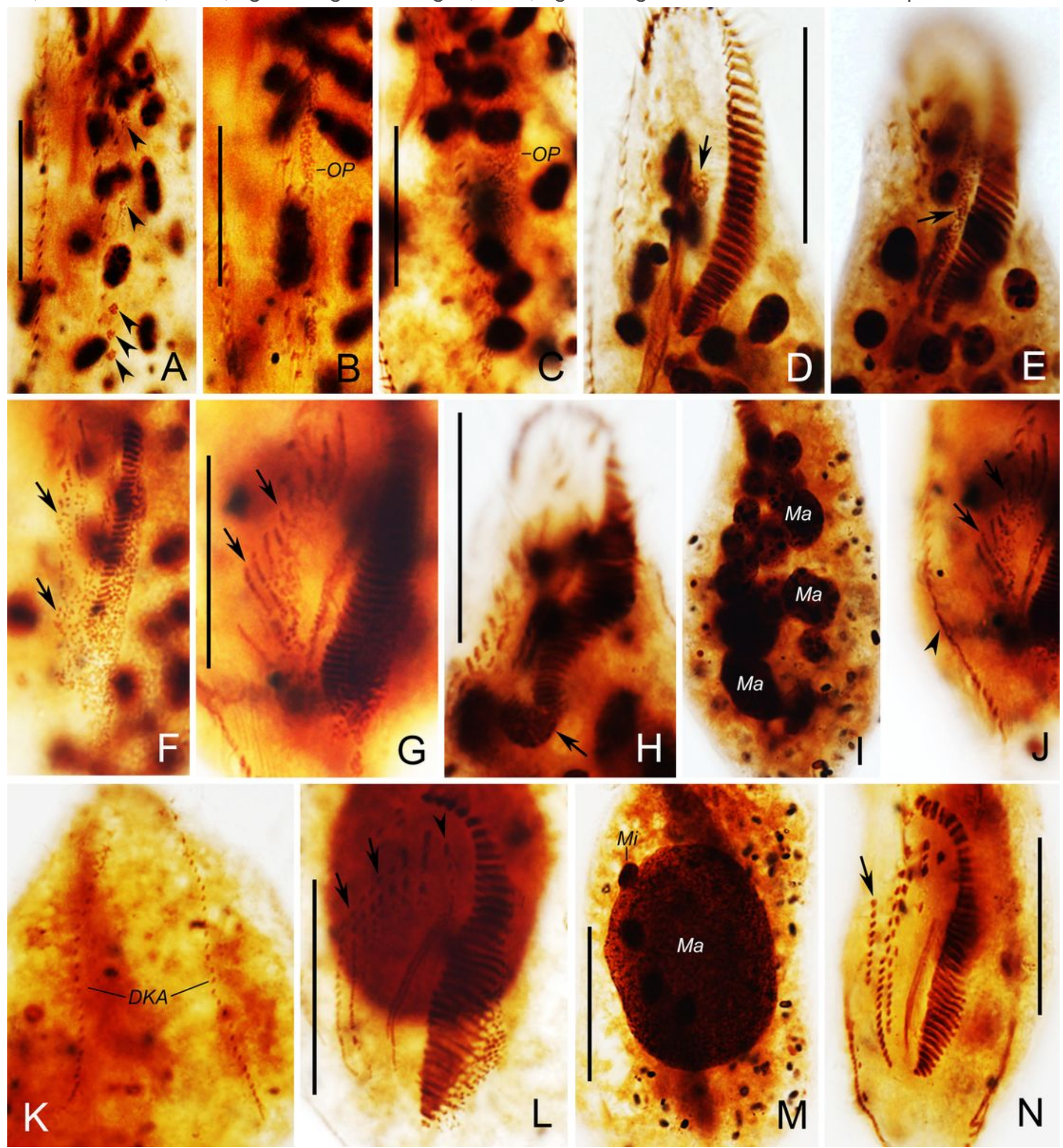

\section{Figure 5}

Photomicrographs of Holostichides songi nov. spec. during morphogenesis, after protargol staining. (AC) Ventral views of early dividers, to show the oral primordium in the opisthe (arrowheads). (D) Ventral view, arrow marks that the basal bodies formed apokinetally. (E) Ventral view, to depict the undulating 
membranes anlage (arrow). (F, G, J) Ventral views, arrows denote the frontoventral-transverse cirral anlagen and arrowhead marks the right marginal anlage. $(\mathrm{H})$ Ventral view, arrow indicates the basal bodies formed at the proximal end of old adoral zone. (I, K) Dorsal views, to show the macronuclear nodules and dorsal kineties anlagen. (L, M) Ventral (L) and dorsal (M) view, to demonstrate the fragmentation of the frontoventral-transverse cirral anlagen (arrows), the leftmost frontal cirrus forming from the undulating membranes anlage (arrowhead) and the fusion of the macronuclear nodules. ( $N$ ) Ventral view, to show newly formed ciliature, arrow marks the frontoterminal cirri. DKA, dorsal kineties anlagen; OP, oral primordium; Ma, macronuclear nodules; Mi, micronuclei. Scale bars = $30 \mu \mathrm{m}$.

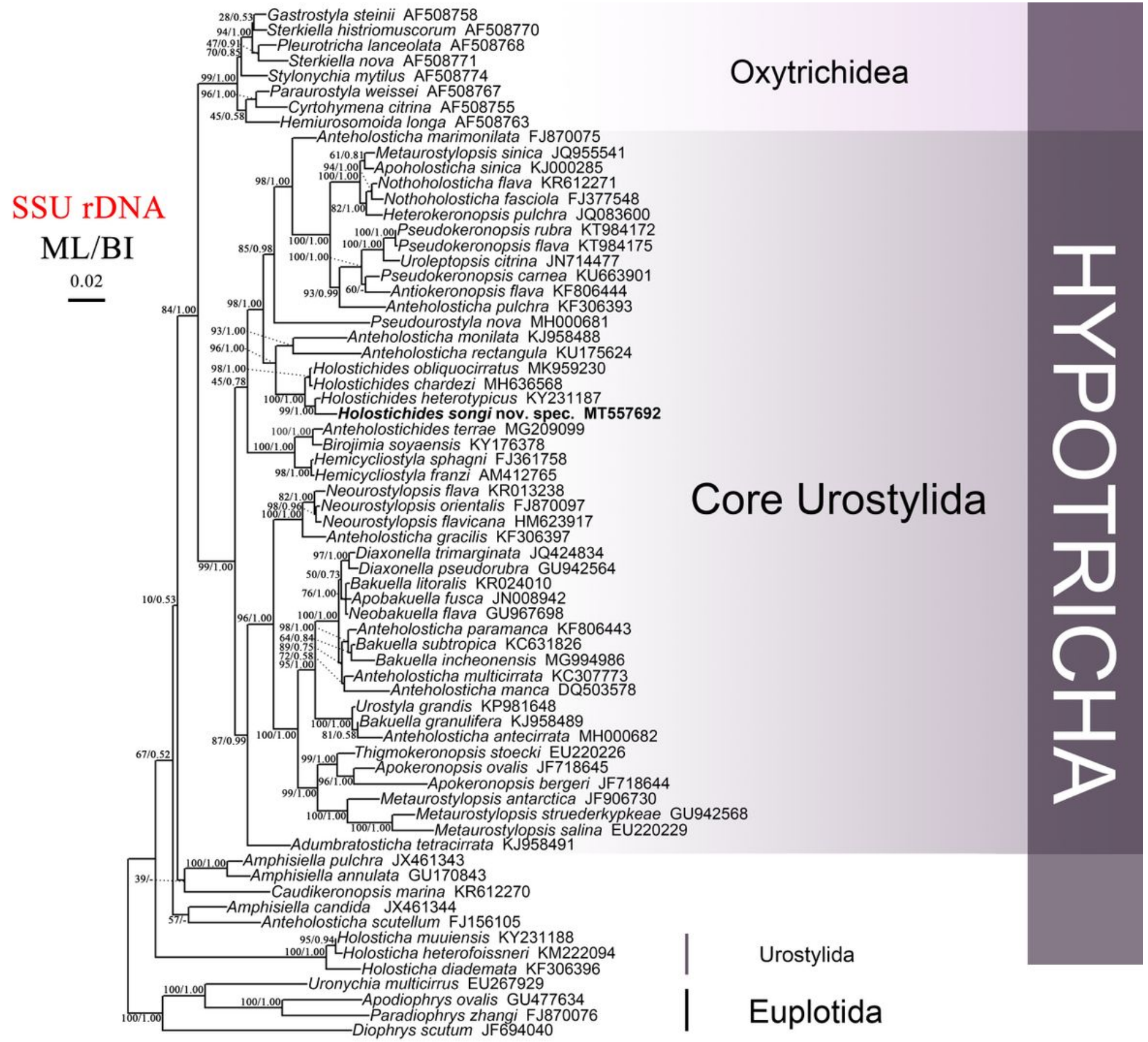

Figure 6 
Maximum likelihood (ML) tree based on the SSU rDNA sequence data. The newly sequenced Holostichides songi nov. spec. is indicated in bold. Support values of nodes are for ML and Bayesian inference (BI), respectively. Clades with a different topology in the BI tree are indicated by "-". All branches are drawn to scale. The scale bar corresponds to 0.02 expected substitutions per site. 